\title{
REPRODUCTIVE EFFICIENCY OF NELLORE (BOS INDICUS) COWS SUBJECT TO BOTH FTAI AND HOMEOPATHIC SUPPLEMENTATION
}

\author{
EFICIENCIA REPRODUTIVA EM VACAS NELORE (BOS INDICUS) \\ SUBMETIDAS À IATF E A SUPLEMENTAÇÃO HOMEOPÁTICA
}

\begin{abstract}
Paulo Francisco Maciel Póvoas SOUTO ${ }^{1}$, Tássia Ferreira PIRES ${ }^{1}$, Pábola Santos NASCIMENTO ${ }^{1}$, José Carlos FERREIRA-SILVA ${ }^{1}$, Marcelo Tigre MOURA ${ }^{2}$, Manoel Lopes SILVA FILHO ${ }^{3}$, Cláudio Coutinho BARTOLOMEU ${ }^{4}$, Marcos Antonio Lemos OLIVEIRA ${ }^{*}$

1. Doutorando em Medicina Veterinária - Universidade Federal Rural de Pernambuco - UFRPE, Recife, PE, Brasil.; 2. Pós Doutorando em Medicina Veterinária - Universidade Federal Rural de Pernambuco - UFRPE, Recife, PE, Brasil.; 3. Professor Doutor - Departamento de Medicina Veterinária - Universidade Federal do Piauí - UFPI, Bom Jesus, PI, Brasil.; 4. Professor Doutor - Departamento de Medicina Veterinária - Universidade Federal Rural de Pernambuco - UFRPE, Recife, PE, Brasil.; maloufrpe@gmail.com
\end{abstract}

\begin{abstract}
The aim of this work was to determine the effect of homeopathic supplementation on both ovarian dynamics and conception rate in Nellore cows subjected to fixed-time artificial insemination (FTAI). Cows $(\mathrm{n}=150)$ were randomly distributed to the control $(\mathrm{CG})$ and the homeopathy group (HG). The HG cows were supplemented with Pró-cio in the mineral salt for 60 days and both experimental groups were further subjected to FTAI. Cows were evaluated for ovarian dynamics $(\mathrm{n}=$ 16), progesterone (P4) concentration $(\mathrm{n}=16)$, and conception rates $(\mathrm{n}=150)$. Ovarian dynamics determined by ultrasonography and showed similar findings for $\mathrm{CG}$ and $\mathrm{HG}$, respectively. Thus follicular diameter $(8.7 \pm 1.0 \mathrm{~mm}$ vs. $10.0 \pm 0.8 \mathrm{~mm})$, mean pre-ovulatory follicle volume $(0.46 \pm 0.15 \mathrm{~mL}$ vs. 0.61 $\pm 0.12 \mathrm{~mL})$, and mean follicular growth $(3.65 \pm 1.41 \mathrm{~mm}$ vs. $4.60 \pm 1.21 \mathrm{~mm})$ did not differ between groups. Moreover, corpus luteum diameter was similar between groups (CG: $16.28 \pm 0.7 \mathrm{~mm}$ vs. HG: $15.6 \pm 0.8 \mathrm{~mm} ; \mathrm{P}>0.05$ ), although P4 levels did differ (CG: $2.55 \pm 0.85 \mathrm{ng} \mathrm{mL}^{-1}$ vs. HG: $6.52 \pm 1.19 \mathrm{ng}$ $\mathrm{mL}^{-1} ; \mathrm{P}<0.05$ ). The conception rate after FTAI was not affected by homeopathic supplementation (CG: $74.67 \%$, and did HG: $77.33 \%$; P > 0.05). In conclusion, the homeopathic supplementation Pró-cio increases $\mathrm{P} 4$ concentrations but does improve the reproductive efficiency of Nellore cows subject to FTAI.
\end{abstract}

KEYWORDS: Corpus luteum. Follicle. Homeopathy. Ovarian dynamics.

\section{INTRODUCTION}

The efficiency of cattle production systems is directly related to its adequate nutritional, sanitary, and reproductive management (FERREIRA-SILVA et al., 2017; TATCHER, 2017). The application of assistedreproduction technologies increases the overall herd genetic merit by delivering more offspring from the most productive animals (HANSEN, 2014). For such approaches, the control of estrous cycles is paramount and is typically attained by hormone-based protocols (BISINOTTO et al., 2014; STEVENSON; BRITT, 2017).

Despite the efficiency of synthetic compounds for estrous cycle control, hormone or pharmacologically-based protocols remain expensive and are not aligned with the increasing demand for hormone-free practices (MARTIN; KADOKAWA, 2006; SILVA FILHO et al., 2015; FERREIRA-SILVA et al., 2017). Thus, the investigation of alternatives for estrous cycle control remains as an attractive research venue. Under such context, homeopathy became a widespread practice in organic farming (HEKTOEN, 2005; LIMA et al., 2016). Homeopathy approaches have also been used in numerous species to treat different diseases by replacing antibiotics, anti-diarrheic, and antihelminthics products (VARSHNEY; NARESH, 2005; CHAGAS et al., 2008; SOTO et al., 2008; WERNER et al., 2010; MATHIE; CLAUSEN, 2015; DOEHRING; SUNDRUM, 2016; ORJALES et al., 2016).

For animal reproduction applications, homeopathy can be used for increasing endogenous hormone production (RAJKUMAR et al., 2006), to improve semen parameters (GERHARD; WALLIS, 2002; LOBREIRO, 2007; SOTO et al., 2009), to treat ovarian pathologies (RAJKUMAR et al., 2006; FIDELAK et al., 2007), and further increase pregnancy rates (WILLIAMSON et al., 1991; 
KUMAR et al., 2004; SOTO et al., 2010). Despite these promising evidences, the efficacy of homeopathic supplementation for improving cattle reproduction needs further investigation.

There is a growing necessity worldwide to increase the fertility rates of commercial beef cattle herds, concomitant with the need for reducing costs while diminishing the utilization of hormone-based protocols. Therefore, the aim of this work was to evaluate the ovarian dynamics and conception rates in Nellore cows subjected to both homeopathic supplementation with Pró-Cio ${ }^{\circledR}$ and fixed-time artificial insemination (FTAI).

\section{MATERIAL AND METHODS}

\section{Location}

Experiments were carried out in Currais, Piauí state, Brazil. The geographic coordinates of the farm are latitude $09^{\circ} 00^{\prime} 25^{\prime \prime}$ South and longitude $44^{\circ} 24^{\prime} 39^{\prime \prime}$ 'West. The altitude is 320 $\mathrm{m}$, with a mean annual temperature of $26.4{ }^{\circ} \mathrm{C}$, and mean annual rainfall of $996 \mathrm{~mm}^{3}$. Animals were raised in cultivated pastures (i.e., Brachiaria brizantha and Andropogon gayanus) and had free access to water and mineralized salt.

\section{Animal Selection and Management}

Multiparous Nellore (Bos indicus) cows used had aged from 3 to 5 years, had delivered within 60 days, and displayed a body condition score between 2.5 and 3.5 in a 1 to 5 scale, as described by BROSTER and BROSTER (1998). The cows were subject to clinical and gynecological examination as recommended by GRUNERT and BIRGEL (1982). Based on these criteria, selected cows $(n=150)$ were randomly allocated to experimental groups (i.e., Control Group - CG and Homeopathy Group - HG).

The homeopathic supplement (Pró-Cio ${ }^{\circledR}$; Real H Nutrição e Saúde Animal) was added to the mineralized salt ( $20 \mathrm{~g}$ per animal each day) to HG cows throughout the experiment (60 days). After the initial 30 days of homeopathic supplementation (adaptation period), cows were subject to an FTAI protocol.

On day 0 (D0), cows of both groups received an intravaginal device $\left(\right.$ Sincrogest ${ }^{\mathbb{B}}$; Ourofino Agronegócio) containing $1 \mathrm{~g}$ progesterone and $2 \mathrm{mg}$ estradiol benzoate (Sincrodiol ${ }^{\circledR}$; Ourofino Agronegócio) by an intramuscular (IM) shot. On day 8 (D8), cows were treated with 500 IU (IM) equine chorionic gonadotropin (Sincro $\mathrm{eCG}^{\mathbb{R}}$; Ourofino Agronegócio), $500 \quad \mu \mathrm{g} \quad$ Cloprostenol (Cloprostenol Sódico; Sincrocio ${ }^{\circledR}$; Ourofino Agronegócio), and $1.0 \mathrm{mg}$ EB at the moment of intravaginal device removal. Forty-four hours after intravaginal implant removal, the FTAI was carried out with frozen-thawed semen from bulls of proven field fertility (semen successfully used for FTAI). The conception rate was determined 40 days after FTAI, as previously described by Pereira et al. (2016). The conception rate was calculated by dividing the total number of pregnant cows by the total number of cows subject to FTAI and further multiplied by 100 . Figure 1 is a schematic representation of the experimental design of the study.

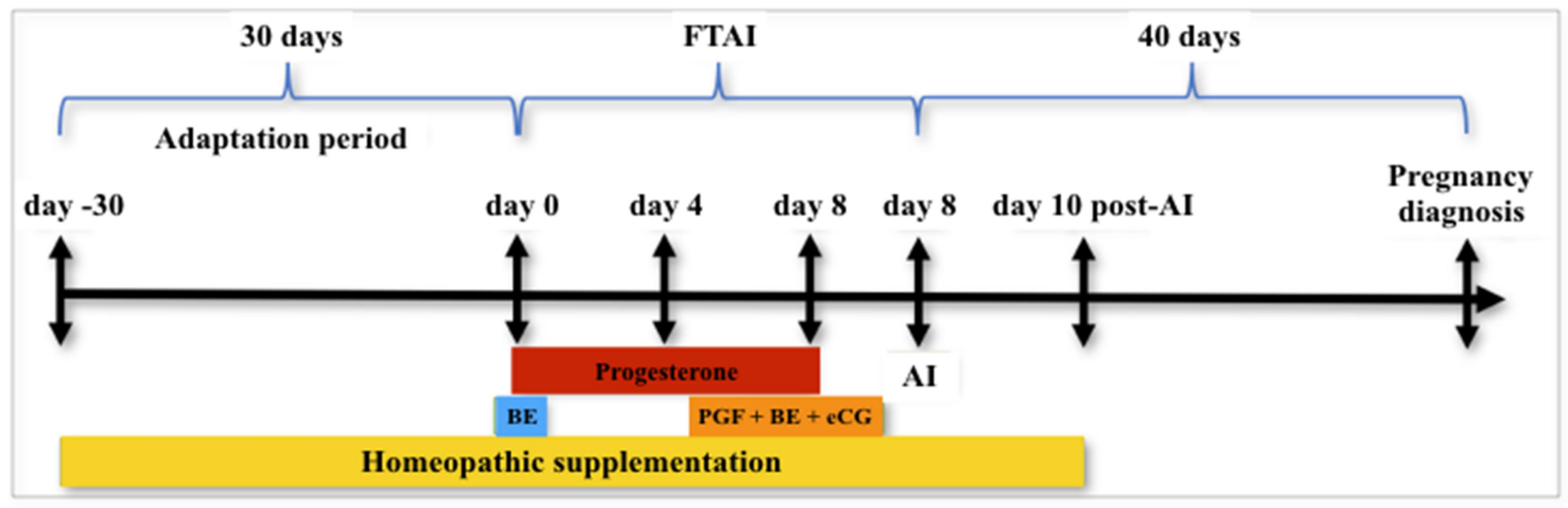

Figure 1. Experimental design to determine the effect of homeopathic supplementation with Pró-Cio ${ }^{\circledR}$ on the reproductive efficiency of Nellore (Bos indicus) subjected to fixed-time artificial insemination (FTAI). AI: artificial insemination. BE: benzoate estradiol. eCG: Equine chorionic gonadotropin. PGF: prostaglandin 2 alpha. 


\section{Ovarian dynamics}

The ovarian dynamics was carried out by ultrasonography. One technician performed all analysis using a single device (Sono Vet R3, Madison) equipped with a linear transducer (7.5 $\mathrm{MHz}$ ). The ovarian activity analysis was performed in eight cows of each group, as previously described (SILVA FILHO et al., 2015). The traits that were analyzed: number of follicles, mean diameter (vertical and horizontal mean diameters) of the dominant follicle, codominant and pre-ovulatory follicles, follicular volume, and further corpus luteum diameter (if found). The exams were carried out at the onset of homeopathic supplementation and in sevenday intervals afterward until estrous synchronization for FTAI. During synchronization, the examinations were carried out on days D0, D4, D8, and D10 and ten days after the FTAI protocol (for corpus luteum measurement).

\section{Progesterone Analysis}

Blood samples were obtained by jugular vein puncture with a $21 \mathrm{G}$ needle into heparincontaining tubes (Becton Dickinson, Rutherford, $\mathrm{NJ})$. The blood was centrifuged $(2,500 \mathrm{~g}$ for 10 minutes) for plasma retrieval and stored at -20 ${ }^{\circ} \mathrm{C}$. The determination of progesterone (P4) concentration was performed by chemiluminescence (Coat-a-Count; Diagnostics Products Corporation). The coefficient of variation of the test was $4.25 \%$, and the minimum detectable level was $0.08 \mathrm{ng} \mathrm{mL}^{-1}$.

\section{Statistical Analysis}

The data generated during each exam was analyzed using the SPSS 16.0. Initially, the data was subject to both critical and consistency analysis (frequencies, distributions, and homogeneity). Moreover, pre-ovulatory follicle diameter and volume, follicular growth between D4 and the day of FTAI, the quantity of recruited follicles on D4, and corpus luteum diameter 10 days after FTAI were determined by analysis of variance (ANOVA). The pregnancy rate and frequency of cows with a new follicular wave were evaluated by the chi-square test. The significance level was $5 \%$.

\section{RESULTS}

Table 1 contains the data relative to the ovarian activity of HG and CG cows. It can be observed that mean POF diameter, mean POF volume, follicular growth (between D4 and D10, and FTAI day), and mean corpus luteum diameter after FTAI did not differ between groups ( $\mathrm{P}>0.05$; Table 1$)$.

Table 1. Mean values \pm SEM for recruited follicles on D4, diameter and volume of the pre-ovulatory follicle on D10, follicular growth between D4 and D10, and corpus luteum diameter at day 10 post-IATF in Nellore cows under homeopathic supplementation with Pró-Cio (HG) and the control group (CG).

\begin{tabular}{lcc}
\hline \multicolumn{2}{c}{ Ovarian Activity } \\
\hline & \multicolumn{2}{c}{ Group } \\
\cline { 2 - 3 } & HG & CG \\
\hline Follicles recruited on D4 & $10.37 \pm 0.94$ & $12.75 \pm 1.66$ \\
Mean pre-ovulatory follicle diameter $(\mathrm{mm})$ & $10.0 \pm 0.8$ & $8.7 \pm 1.0$ \\
Mean pre-ovulatory follicle volume $(\mathrm{mL})$ & $0.61 \pm 0.12$ & $0.46 \pm 0.15$ \\
Mean follicular growth between D4 and D10 (mm) & $4.60 \pm 1.21$ & $3.65 \pm 1.41$ \\
Mean Corpus Luteum diameter post-FTAI (mm) & $15.60 \pm 0.8$ & $16.28 \pm 0.7$ \\
\hline
\end{tabular}

No statistical difference was found between groups $(\mathrm{P}>0.05)$.

The distribution of ovarian follicles according to their size is shown below (Figure 2). There was no difference $(\mathrm{P}>0.05)$ between groups for follicle size interval. Moreover, mean follicular growth during the FTAI protocol was also determined (Figure 3). 


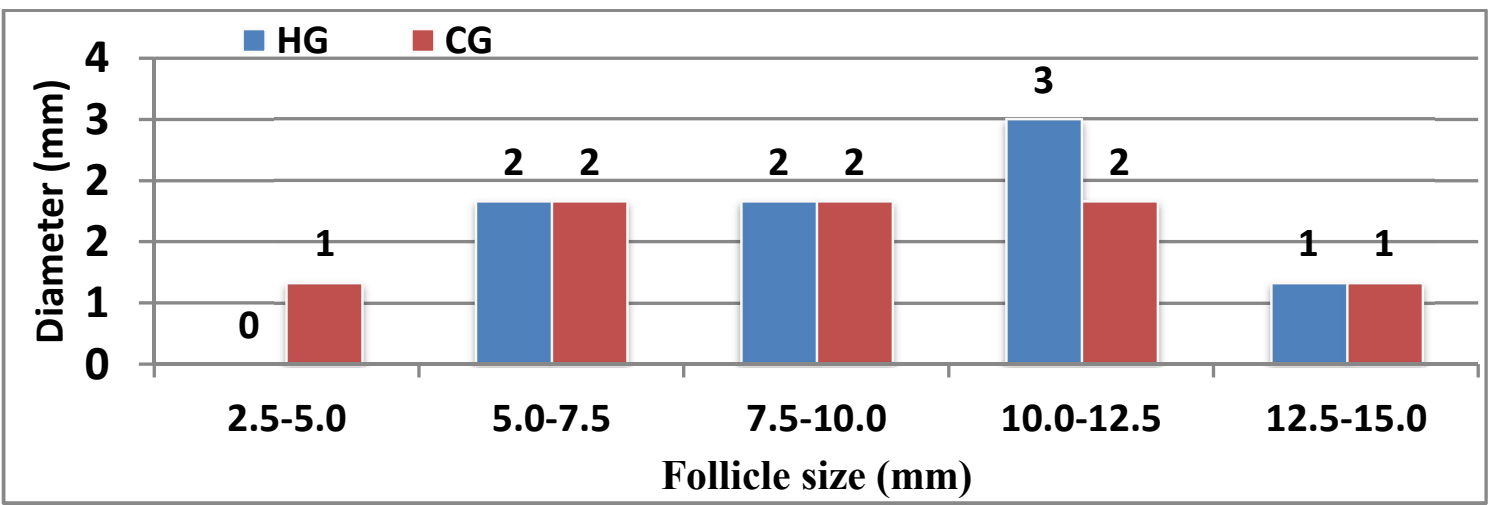

Figure 2. Follicle size in Nellore cows (Bos indicus) under homeopathic supplementation with Pró-Cio (HG) or the control group (CG).

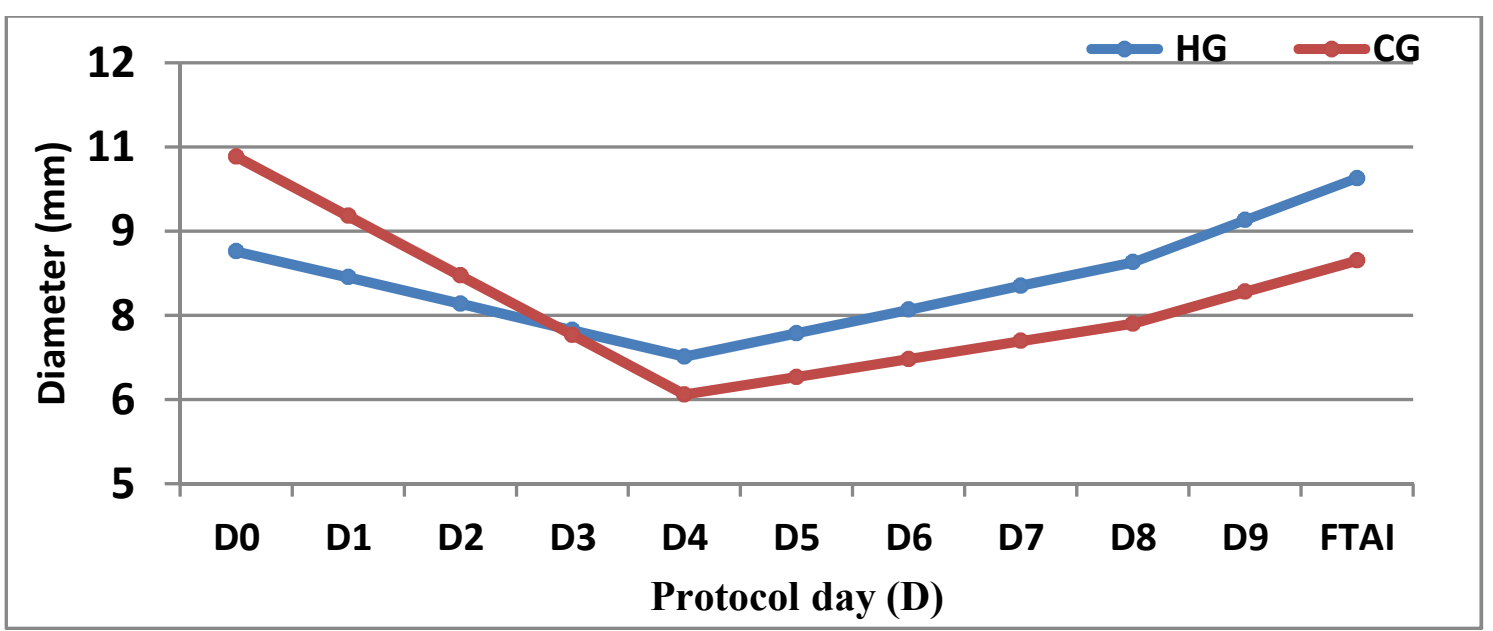

Figure 3. Follicular growth during the FTAI protocol (from day 4 until day 10) in Nellore cows (Bos indicus) under homeopathic supplementation with Pró-Cio (HG) or the control group (CG).

Figure 4 displays the data relative to mean corpus luteum (CL) diameter and P4 concentration in both $\mathrm{HG}$ and the $\mathrm{CG}$ at day 10 post-FTAI. No difference was found $(\mathrm{P}>0.05)$ between groups for CL diameter, but $\mathrm{P} 4$ levels were higher $(\mathrm{P}<0.05)$ on the HG than in the $\mathrm{CG}$. The conception rate in the HG was $77.33 \%$ $(58 / 75)$ and $74.67 \%(56 / 75)$ in the CG, with no difference $(\mathrm{P}>0.05)$ between groups.

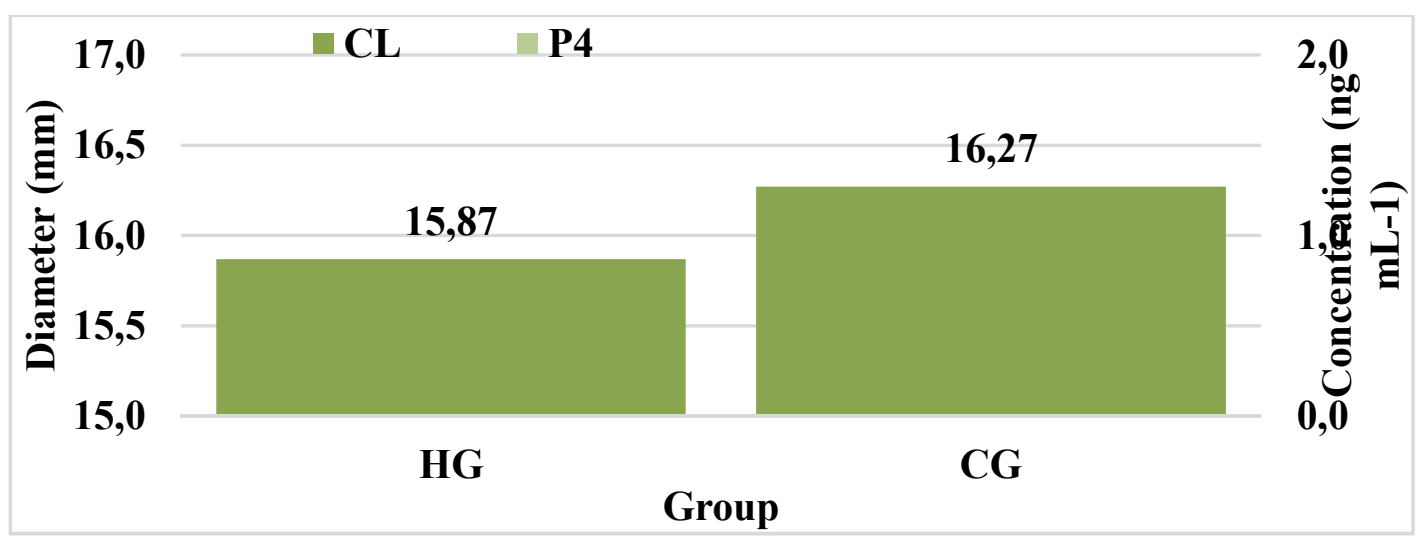

Figure 4. Relationship between Corpus Lutem diameter (CL) and progesterone concentration (P4) at day 10 post-FTAI in Nellore cows (Bos indicus) under homeopathic supplementation with PróCio (HG) or the control group (CG). 


\section{DISCUSSION}

The diameter of pre-ovulatory follicles correlates with ovulation potential (SARTORI et al., 2001; GIMENES et al., 2008), with CL diameter (VASCONCELOS et al., 2001), and ultimately with conception rate (PERRY et al., 2007). Collectively, these parameters interplay to establish cow fertility and thus lead to determine herd overall reproductive performance.

The data described above showed that homeopathic treatment with Pró-cio ${ }^{\circledR}$ did not lead to increased follicular development. Therefore, it can be ruled out that the protocol does not induce affect the cyclicity status. This reasoning is not supported by findings from RAJKUMAR et al. (2006), who found that a homeopathic supplement could be used for reverting cow anestrus. The increased estradiol concentration could be due to the addition of different plants (i.e., Pulsatilla spp. and Aletris farinosa) to this homeopathic supplement (BOERICKE, 2001; DUKE et al., 2002). In buffaloes, combinations of homeopathic products also reduced anestrus incidence (KUMAR et al., 2004).

Pre-ovulatory follicles in HG cows reached $7.5 \mathrm{~mm}$ or more, while follicles from some animals had reached $12 \mathrm{~mm}$. This fact was suggestive that conception rates would be increased by improving ovulation rates, since dominant follicle dilation in Bos indicus occurs when reaching $7 \mathrm{~mm}$ (GIMENES et al., 2008). This reasoning is also supported by the relationship between pre-ovulatory follicle size, CL diameter and the $\mathrm{P} 4$ production potential. Within smaller follicle sizes, the resulting lower P4 concentration would not enough for blocking prostaglandin synthesis by the endometrium (VASCONCELOS et al., 2001) and thus inhibit premature luteolysis (BRIDGES et al., 2005).

The number of follicles that were recruited on D4 was not increased by the homeopathic supplementation. Comparison with previous data is somewhat difficult due to the varying methodological approaches and definition of minimum antral follicle size (FERREIRA et al., 2004; STARBUCK-CLEMMER et al., 2007; SÁ FILHO et al., 2008). However, some reports have pointed out to differences in reproductive physiology between Bos indicus and Bos taurus (i.e., mean recruited follicles and dominant follicle size). Such differences could be due to some physiological parameters, such as higher IGF-I and insulin serum concentrations and elevated FSH-responsiveness (SILVA-SANTOS et al., 2011; SARTORI; BARROS, 2011).
The follicle size in HG was higher than the $\mathrm{CG}$ cows, but $\mathrm{CL}$ was indistinguishable between groups. More recent reports have shown that the P4 production is not exclusively dependent on $\mathrm{CL}$ diameter, but is also influenced by its vasculature. In Bos indicus cows, the estrus $\mathrm{P} 4$ concentration is approximately $1 \mathrm{ng} \mathrm{mL}^{-1}$ but can reach $4.5 \mathrm{ng} \mathrm{mL}^{-1}$ ten days later (ADEYEMO; HEATH, 1980). Since P4 concentrations differed between groups, independently of CL diameter, other factors (e.g., blood flow fluctuations, the presence of luteotropic or luteolytic factors, and different availability of P4 precursors) may have accounted for such difference (WILTBANK, 1994).

Conception rates were not affected by the homeopathic supplementation. This result may be context-dependent or breed-dependent since Penteado et al. (2005) found the homeopathic product may increase cyclicity and pregnancy rates in dairy cattle. Another important factor is that eCG favors pregnancy rates after FTAI in postpartum cows (BARUSELLI et al., 2004) and thus may have masked the beneficial effect of homeopathic supplementation. Another applausive concern is that some animals may not have ingested enough homeopathic supplement during the experiment. However, this fact can be ruled out due to two reasons. Firstly, cows subjected to homeopathic supplementation displayed higher P4 levels, suggesting a physiological response from all cows under such conditions. Secondly, supplementation of mineral sat with different compounds influences reproductive traits in both cows and bulls (JUCHEM et al., 2010; REIS et al., 2014).

In conclusion, the homeopathic supplementation Pró-cio increases P4 concentrations but does improve the reproductive efficiency of Nellore cows subject to FTAI.

\section{Conflict of Interest}

The authors declare no conflict of interest.

\section{Ethics Committee}

The experiment was approved by "Comissão de Ética e Experimentação Animal CEUA" from the Universidade Federal Rural de Pernambuco (Protocol 060/2013).

\section{ACKNOWLEDGMENTS}

The authors would like to acknowledge the Arenales Fauna e Flora Homeopatia Animal 
Company for providing the homeopathic product, to $\mathrm{CNPq}$ for the Master's degree scholarship (PFMPS), and to Pasqual Rotilli for providing the animals and the farm instructor for the study. M.T.M. is a PNPD-CAPES fellow.

RESUMO: O objetivo foi determinar o efeito da suplementação homeopática na dinâmica ovariana e taxa de concepção em vacas Nelore cows submetidas à inseminação artificial em tempo fixo (IATF). As vacas $(n=150)$ foram distribuídas aleatoriamente nos grupos controle $(\mathrm{GC})$ e grupo homeopático $(\mathrm{GH})$. As vacas do GH foram suplementadas com Pró-cio ${ }^{\mathbb{B}}$ no sal mineral mineral por 60 dias. Ambos os grupos foram submetidos à IATF. As vacas foram avaliadas quanto à dinâmica ovariana $(\mathrm{n}=16)$, concentração de progesterona $(\mathrm{P} 4 ; \mathrm{n}=16)$ e taxa de concepção $(\mathrm{n}=150)$. A dinâmica ovarina foi determinada por ultra-sonografia e mostrou resultados semelhantes para o GC e o GH, respectivamente. Portanto, para diâmetro folicular $(8,7 \pm 1,0 \mathrm{~mm}$ vs. $10,0 \pm 0,8 \mathrm{~mm})$, volume médio do folículo pré-ovulatório $(0,46 \pm 0,15 \mathrm{~mL}$ vs. $0,61 \pm 0,12 \mathrm{~mL})$ e crescimento folicular médio $(3,65 \pm 1,41$ $\mathrm{mm}$ vs. 4,60 $\pm 1,21 \mathrm{~mm}$ ) não diferiram entre os grupos. Além disso, o diâmetro do corpo lúteo foi semelhante entre os grupos (CG: 16,28 $\pm 0,7 \mathrm{~mm}$ vs. HG: 15,6 $\pm 0,8 \mathrm{~mm} ; \mathrm{P}>0.05$ ), apesar dos níveis de P4 diferirem (CG: $2,55 \pm 0,85 \mathrm{ng} \mathrm{mL}^{-1}$ vs. GH: $\left.6,52 \pm 1,19 \mathrm{ng} \mathrm{mL}^{-1} ; \mathrm{P}<0.05\right)$. A taxa de concepção após a IATF não foi afetada pela suplementação homeopática (GC:74.67 \% vs. GH: 77.33 \%; P > 0.05). Em conclusão, a suplementação homeopática com Pró-cio aumenta a concentração de P4 mas não melhora a eficiência reprodutiva de vacas Nelore cows submetidas à IATF.

PALAVRAS-CHAVE: Corpo lúteo. Folículo. Homeopatia. IATF.

\section{REFERENCES}

ADEYEMO, O.; HEATH, E. Plasma progesterone concentration in Bos taurus and Bos indicus heifers. Theriogenology, v. 14, n. 6, p. 411-420, 1980. https://doi.org/10.1016/0093-691X(80)90052-7

BARUSELLI, P. S.; BÓ, G. A.; REIS, E. L.; MARQUES, M. O. Inseminação artificial em tempo fixo em bovinos de corte. In: Simpósio Internacional de Reprodução Animal Aplicada, 10, Londrina, 2004. Anais... Londrina, p.155-165, 2004.

BISINOTTO, R.S.; RIBEIRO, E.S.; SANTOS, J.E. Synchronisation of ovulation for management of reproduction in dairy cows. Animal. v. 8 Supplement 1, p. 151-159, 2014. https://doi.org/10.1017/S1751731114000858

BOERICKE, W. Pocket Manual of Homeopathic Materia Medica, 9th ed. NewDelhi: Indian Books and Periodicals Publishers, 2001.

BRIDGES, G. A.; GASSER, C. L.; GRUM, D. E.; MUSSARD, M. L.; HELSER, L. A.; DAY, M. L. Influence of reducing the interval between GnRH and PGF ( 2 alpha) to 5 days on reproductive performance of cows synchronized with GnRH-CIDR-PGF ( 2 alpha) programs. Journal of Dairy Science, v. 88, p. 169, 2005.

BROSTER, W. H.; BROSTER, V. J. Body score of dairy cows, Journal Dairy Research, v. 65, n. 1, p. 155-173, 1998. https://doi.org/10.1017/S0022029997002550

CHAGAS, A.C. S.; VIEIRA, L. S.; FREITAS, A. R.; ARAÚJO, M. R. A.; ARAÚJO-FILHO, J. A.; ARAGUAO, W. R.; NAVARRO, A. M. C. Anthelmintic efficacy of neem (Azadirachta indica A. Juss) and the homeopathic product Fator Vermes ${ }^{\circledR}$ in Morada Nova sheep. Veterinary Parasitology, v. 151, n. 1, p. 68-73, 2008. https://doi.org/10.1016/j.vetpar.2007.10.003 
DOEHRING, C.; SUNDRUM, A. Efficacy of homeopathy in livestock according to peer-reviewed publications from 1981 to 2014. Veterinary Record, v. 179, n. 24, 628, 2016.

https://doi.org/10.1136/vr.103779

DUKE, J. A. HandBook of Medicinal Herbs, $2^{\text {nd }}$ ed. Boca Raton, FL: CRC Press, 2002. 843p. https://doi.org/10.1201/9781420040463

FERREIRA, A. M.; VIANA, J. H. M.; CAMARGO, L. S. A.; SÁ, W. F.; PEREIRA, P. A. C. População Folicular Ovariana Durante o Ciclo Estral em Vacas da Raça Gir. Revista Brasileira de Zootecnia, v. 33, n. 1, p. 1689-1694, 2004. https://doi.org/10.1590/S1516-35982004000700007

FERREIRA-SILVA, J. C.; BASTO, S.; TENÓRIO FILHO, F.; MOURA, M.T.; SILVA FILHO, M.L.; OLIVEIRA, M. Reproductive performance of postpartum ewes treated with insulin or progesterone hormones in association with ram effect. Reproduction in Domestic Animals, v. 52, 610-616, 2017. https://doi.org/10.1111/rda.12956

FIDELAK, C.; KLOCKE, P.; HEUWIESER, W. Homeopathic prophylaxis in dairy cows on an organic farm: part 1: fertility. Dtsch Tierarztl Wochenschr, v. 114, n. 7, p. 268-274, 2007.

GERHARD, I.; WALLIS, E. Individualized homeopathic therapy for male infertility. Homeopathy, v. 91, n. 3, p. 133-144, 2002. https://doi.org/10.1054/homp.2002.0024

GIMENES, L. U.; SÁ FILHO, M. F.; CARVALHO, N. A.; TORRES-JÚNIOR, J. R.; SOUZA, A. H.; MADUREIRA, E. H.; TRINCA, L. A.; SARTORELLI, E. S.; BARROS, C. M.; CARVALHO, J. B.; MAPLETOFT, R. J.; BARUSELLI, P. S. Follicle deviation and ovulatory capacity in Bos indicus heifers. Theriogenology, v. 69, n. 7, p. 852-858, 2008.

https://doi.org/10.1016/j.theriogenology.2008.01.001

GRUNERT, E.; BIRGEL, E.H.Obstetrícia Veterinária. Porto Alegre:Sulina, 1982.

HANSEN, P.J. Current and future assisted reproductive technologies for mammalian farm animals. Advances in Experimental Medicine and Biology, v. 752, p. 1-22, 2014. https://doi.org/10.1007/9781-4614-8887-3_1

HEKTOEN, L. Review of the current involvement of homeopathy in veterinary practice and research. The Veterinary Record, v. 157, n. 8, p. 224-229, 2005. https://doi.org/10.1136/vr.157.8.224

JUCHEM, S.O.; CERRI, R.L.; VILLASEÑOR M, GALVÃO KN, BRUNO RG, RUTIGLIANO HM, DEPETERS EJ, SILVESTRE FT, THATCHER WW, SANTOS JE. Supplementation with calcium salts of linoleic and trans-octadecenoic acids improves fertility of lactating dairy cows. Reproduction in Domestic Animals, v. 45, n. 1, p. 55-62, 2010. https://doi.org/10.1111/j.1439-0531.2008.01237.x

KUMAR, H.; SRIVASTAVA, S. K.; YADAV, M. C.; VARSHNEY, J. P. Management of postpartum anoestrus in dairy animals with a homeopathic combination remedy. Indian Journal of Animal Sciences, v. 74, n.7, p. 739-740, 2004.

LIMA, L. F.; BRUNO, J. B.; RODRIGUES, A. P. R.; FIGUEIREDO, J. R. Papel da homeopatia na regulação da foliculogênese in vivo e in vitro. Reprodução \& Climatério, v. 31, n. 2, p. 112-119, 2016. https://doi.org/10.1016/j.recli.2016.04.004

LOBREIRO, J. Homeopathic treatment for infertility in a prize Nelore bull. Homeopathy, v. 96, n. 1, p. 49-51, 2007. https://doi.org/10.1016/j.homp.2006.10.003 
MARTIN, G. B.; KADOKAWA, H."Clean, green and ethical" animal production. case study: reproductive efficiency in small ruminants. Journal of Reproduction and Development, v. 52, n. 1, p. 145-152, 2006. https://doi.org/10.1262/jrd.17086-2

MATHIE, R.T.; CLAUSEN, J. Veterinary homeopathy: systematic review of medical conditions studied by randomised trials controlled by other than placebo. BMC Veterinary Research, v. 11, 236, 2015. https://doi.org/10.1186/s12917-015-0542-2

ORJALES, I.; LÓPEZ-ALONSO, M.; RODRÍGUEZ-BERMÚDEZ, R.; REY-CRESPO, F.; VILLAR, A.; MIRANDA, M. Use of homeopathy in organic dairy farming in Spain. Homeopathy, v. 105, n. 1, 102-108, 2016. https://doi.org/10.1016/j.homp.2015.08.005

PENTEADO, L.; SÁ FILHO, M. F.; REIS, E.L.; TORRES-JÚNIOR, J. R. S.; MADUREIRA, E. H.; BARUSELLI, P. S.Eficiência reprodutiva em vacas Nelore (Bos indicus) lactantes submetidas a diferentes manejos durante a estação de monta. Anais XVI Reunião do Colégio Brasileiro de Reprodução Animal, 2005.

PEREIRA, M. H. C.; WILTBANK, M. C.; VASCONCELOS, J. L. M. Expression of estrus improves fertility and decreases pregnancy losses in lactating dairy cows that receive artificial insemination or embryo transfer. Journal of Dairy Science, v. 99, n. 3 p. 2237-2247, 2016.

https://doi.org/10.3168/jds.2015-9903

PERRY, G. A.; SMITH, M. F.; ROBERTS, A. J.; MACNEIL, M. D.; GEARY, T. W. Relationship between size of the ovulatory follicle and pregnancy success in beef heifer. Journal of Animal Science, v. 85 , n. 3, p. $684-689,2007$. https://doi.org/10.2527/jas.2006-519

RAJKUMAR, R.; SRIVASTAVA, S. K.; YADAV, M. C.; VARSHNEY, V. P.; VARSHNEY, J. P.; KUMAR, H. Effect of homeopathic complex on oestrus induction and hormonal profile in anoestrus cows. Homeopathy, v. 95, n. 3, p. 131-135, 2006. https://doi.org/10.1016/j.homp.2006.03.002

REIS, L.S.; RAMOS, A.A.; CAMARGOS, A.S.; OBA, E. Effect of manganese supplementation on the membrane integrity and the mitochondrial potential of the sperm of grazing Nelore bulls. Animal Reproduction Science, v. 150, n. 1-2, p. 1-6, 2014. https://doi.org/10.1016/j.anireprosci.2014.06.033

SÁ FILHO, M. F.; GIMENES, L. U.; SALES, J. N. S.; CREPALDI, G. A.; MEDALHA, A. G.; BARUSELLI, P. S. IATF em novilha. Biotecnologia da reprodução em bovinos. $3^{\circ}$ Simpósio Internacional de Reprodução Animal Aplicada, Londrina, p. 54-67, 2008. Disponível em: $<\mathrm{http}$ ://fazendaparaiso.net/assets/iatf-em-novilhas.pdf > Acesso em: 25 jul. 2017.

SARTORI, R.; BARROS, C. M. Reproductive cycles in Bos indicus cattle. Animal Reproduction Science, v. 124, n. 3-4, p. 244-250, 2011. https://doi.org/10.1016/j.anireprosci.2011.02.006

SARTORI, R.; FRICKE, P. M.; FERREIRA, J. C.; GINTHER, O. J.; WILTBANK, M. C. Follicular deviation and acquisition of ovulatory capacity in bovines follicles. Biology of Reproduction, v. 65, n. 5, p. 1403-1409, 2001. https://doi.org/10.1095/biolreprod65.5.1403

SILVA FILHO, M. L.; BEZERRA, L. R.; FERREIRA-SILVA, J. C.; SOUTO, F. M. P. P.; OLIVEIRA, N. R. P.; LIMA, P. F.; BARTOLOMEU, C. C.; OLIVEIRA, M. A. L. Influence of biostimulation and temporary weaning on follicular dynamics and pregnancy rates in Nelore cows (Bos taurus indicus). Tropical Animal Health and Production, v.47, n. 7, p. 1285-1291, 2015.

https://doi.org/10.1007/s11250-015-0861-0 
SILVA-SANTOS, K. C.; SANTOS, G. M.; SILOTO, L. S.; HERTEL, M. F.; ANDRADE, E. R.; RUBIN, M. I.; STURION, L.; MELO-STERZA, F. A.; SENEDA, M. M. Estimate of the population of preantral follicles in the ovaries of Bos taurus indicus and Bos taurus taurus cattle. Theriogenology, $\mathrm{v}$. 76, n. 6, p. 1051-1057, 2011. https://doi.org/10.1016/j.theriogenology.2011.05.008

SOTO, F. R. M.; VUADEN, E.R.; BENITES, N. R.; BONAMIN, L. V.; AZEVEDO, S. S. A randomized controlled trial of homeopathic treatment of weaned piglets in a commercial swine herd. Homeopathy, v. 97, n. 4, p. 202-205, 2008. https://doi.org/10.1016/j.homp.2008.09.002

SOTO, F. R. M.; VUADEN, E. R.; COELHO, C. D. P.; BONAMIN, L. V.; AZEVEDO, S. S.; BENITES, N. R. Effect of Avena sativa CH6 in the metabolism of diluted semen of swine. Veterinária e Zootecnia, v. 16, n. 2, p. 367-372, 2009.

SOTO, F. R. M.; VUADEN, E. R.; COELHO, C. D. P.; BONAMIN, L. V.; AZEVEDO, S. S. D.; BENITES, N. R.; MARQUES, M. G. Reproductive performance of sows inseminated with diluted semen treated with homeopathic medicine. International Journal of High Dilution Research, v. 9, n. 30, p. $51-57,2010$.

STARBUCK-CLEMMER, M. J.; HERNANDEZ-FONSECA, H.; AHMAD, N.; SEIDEL, G.; INSKEEP, E. K. Association of Fertility with Numbers of Antral Follicles within a Follicular Wave During the Oestrous Cycle in Beef Cattle. Reproduction in Domestic Animals, v. 42, n. 4, p. 337-342, 2007. https://doi.org/10.1111/j.1439-0531.2006.00786.x

STEVENSON, J.S.; BRITT, J.H. A 100-Year Review: Practical female reproductive management. Journal of Dairy Science, v. 100, n. 12, p.10292-10313, 2017. https://doi.org/10.3168/jds.2017-12959

THATCHER, W.W. A 100-Year Review: Historical development of female reproductive physiology in dairy cattle. Journal of Dairy Science,v. 100, n.12, p. 10272-10291, 2017.

https://doi.org/10.3168/jds.2017-13399

VARSHNEY, J.P.; NARESH, R. Comparative efficacy of homeopathic and allopathic systems of medicine in the management of clinical mastitis of Indian dairy cows. Homeopathy, v. 94, n. 2, p. 81-85, 2005. https://doi.org/10.1016/j.homp.2004.11.013

VASCONCELOS, J. L. M.; SARTORI, R.; OLIVEIRA, H. N.; GUENTHER, J. G.; WILTBANK, M. C. Reduction in size of the ovulatory follicle reduces subsequent luteal size and pregnancy rate.

Theriogenology, v. 56, n. 2, p. 307-314, 2001. https://doi.org/10.1016/S0093-691X(01)00565-9

WERNER, C.; SOBIRAJ, A.; SUNDRUM, A. Efficacy of homeopathic and antibiotic treatment strategies in cases of mild and moderate bovine clinical mastitis. Journal of Dairy Research, v. 77, n. 4, p. 460-467, 2010. https://doi.org/10.1017/S0022029910000543

WILLIAMSON, A. V.; MACKIE, W. L.; CRAWFORD, W.J.; RENNIE, B. A study using Sepia 200c given prophylactically postpartum to prevent anoestrus problems in the dairy cow. British Homoeopathic Journal, v. 80, n. 3, p. 149-156, 1991. https://doi.org/10.1016/S0007-0785(05)80226-1

WILTBANK, M. C. Cell types and hormonal mechanisms associated with mid cycle corpus luteum function. Journal Animal Science, v. 72, n. 7, p. 1873-1883, 1994.

https://doi.org/10.2527/1994.7271873x 